MISSOURI ASSOCIATION OF COLLEGE AND RESEARCH LIBRARIES

Minutes of the Spring Meeting APRIL 21, 1967

The spring meeting of the Missouri Association of College and Research Libraries was held at the University of Missouri in Columbia on Friclay, April 21. Approximately one hundred and twenty were registered representing thirtythree colleges and universities.

Following registration and coffee hour the meeting was called to order in the auditorium of the Student Union by president William A. Martin. The other officers of the association were introduced as was the editor of the MACRL Newsletter. These are: George Hartje, vice president; Robert Harvey, secretary-treasurer; William Cohn, editor.

Mr. Martin then introduced Ralph Parker, librarian of the University of Missouri and dean of its graduate school of library and information science. Dr. Parker spoke on automation in the university library giving something of its history, its present status, and the plans and hopes for the future. Describing fully-automated libraries as one of the most complex and so-

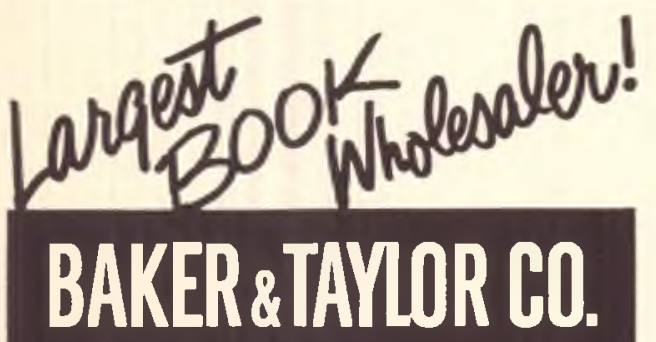

IN EACH OF OUR 3 MAJOR WAREHOUSES: 1,500,000 books ... 100,000 different titles from 1,200 publishers... fastest, most complete and accurate book service.

\section{EASTERN DIVISION}

Telephone: $201-923 \cdot 3200$

N.Y.C. Tel: BArclay 7.8970

MIDWEST AND SOUTHERN DIVISION MOMENCE, ILLINOIS 6095Telephone: 815-472-24t4 Chicago Tel: $346-4074$
HILLSIDE, N.J. 07205

\section{WESTERN DIVISION}

RENO, NEYADA 89502

380 Edison $W$ ay

Telephone: 702.786 .6700

\section{NTERSTATE LIBRARY} SERVICE CO.

A wholly-owned subsidiary 4600 N. Cooper

Oklahoma City, Okla. 731 8 (405) JA 5.6561
BOOK INSPECTION CENTER: The Baker \& Taylor Co. of Texas, Inc. 1701 W. Gray St., Houston, Texas 77019 phisticated of all computer problems, Dr. Parker described the three subsystems of the library's automation plan. These are the acquisitions and fiscal subsystem, the bibliographical subsystem and the inventory control subsystem. About one half of the entire system is now completed and in operation.

Following Dr. Parker's informative talk a short business meeting was held. The minutes of the fall 1966 meeting held in Kansas City were read and approved.

A nominating committee consisting of Harry Voigt, chairman, Alma Bennett and Barbara Palling, was appointed by Mr. Martin for the purpose of nominating a secretary for 1968 . The nominating committee will present their report at the fall meeting of MACRL in St. Louis.

State librarian Charles O'Halloran was introduced. Mr. O'Halloran explained that money was available under Title III of the Library Services and Construction Act for the purpose of undertaking cooperative projects between all types of libraries, including academic. A meeting was held in Jefferson City on May 12 to discuss possibilities for cooperative projects.

Mr. O'Halloran also announced the undertaking of a public information program to better present libraries and their services to all the people of the state. He also mentioned the possibility of the state library providing expanding service to the state government with perluaps a legislative and governmental reference branch of the library being provided in Jefferson City.

A. P. Marshall talked briefly on the cooperative projects aspects of Title II of the Higher Education Act of 1965 stating that funds therefrom would be available to implement the Downs survey.

The meeting adjourned at 11:45 A,M. for a delightful buffet luncheon in the Student Union. John W. Schwada, chancellor of the university, welcomed the members of the association. Principal speaker at the luncheon was Ralph Lowenstein, editor of The Freedom of Information Digest. Mr. Lowenstein reported on a research project which he directed to determine the relationship between the degree of press freedom in a country and the amount of democratization of the country.

Following luncheon tours were conducted of the automated systems in the University of Missouri library.

Also at this time Ralph Parker met with some of the librarians and their staff members who are involved in teaching library science courses. The purpose of the meeting was to discuss the coordination of content and course organization between the undergraduate schools and the school of library and information science at the university.-Robert D. Harvey, secretary.
므. 